\title{
Comparative analysis of online stores
}

\section{Analiza porównawcza sklepów internetowych}

\author{
Arkadiusz Zbigniew Wójtowicz*, Marek Miłosz \\ Department of Computer Science, Lublin University of Technology, Nadbystrzycka 36B, 20-618 Lublin, Poland
}

\begin{abstract}
This article raises issues of online stores. An analysis of many aspects of sales platforms was carried out, such as awareness about existence of these platforms, frequency of purchases, interface quality, intuitiveness, safety and their popularity. Allegro, Amazon, Aliexpress, Ebay and Wish were selected from the most popular online stores. In addition, a survey was conducted and analysed, which examines the awareness and experiences of online stores users. This article allowed us to draw relevant conclusions about these sales platforms and their community.
\end{abstract}

Keywords: e-commerce; online stores

\section{Streszczenie}

Niniejszy artykuł porusza kwestie sklepów internetowych. Przeprowadzono analizę dotyczącą wielu aspektów platform sprzedażowych takich jak świadomość o istnieniu poszczególnych platform, częstotliwość dokonywania zakupów, jakość interfejsu, intuicyjność, bezpieczeństwo i ich popularność. Spośród najpopularniejszych sklepów internetowych wybrano Allegro, Amazon, Aliexpress, Ebay oraz Wish. Ponadto została przeprowadzona i odpowiednio przeanalizowana ankieta, której celem było zdobycie informacji o świadomości oraz o doświadczeniach użytkowników związanych z sklepami internetowymi. Całość pracy pozwoliła wyciągnąć odpowiednie wnioski na temat analizowanych platform sprzedażowych i społeczności ich budujących.

Słowa kluczowe: handel elektroniczny; sklepy internetowe

*Corresponding author

Email address: arkadiusz.wojtowicz@pollub.edu.pl (A. Z. Wójtowicz)

CPublished under Creative Common License (CC BY-SA v4.0)

\section{Introduction}

Online stores gain more and more popularity from year to year. The first appeared in the nineties. Every day, their creators develop these platforms, from year to year, gaining new customers. Initially, the greater part of trade in goods was carried out in stationary stores, where customers personally made shopping. However, along with the development of technology, the tendency changed towards e-stores. Many websites and mobile applications have been created, from which they can directly order products to their homes or other pick-up point. Thanks to this, consumers gained the opportunity to buy objects not only in their city, but also around the country, and even worldwide with only one click. In addition, the situation caused by the coronavirus contributed to the next increase in the importance of ecommerce. When most stationary stores were closed for many months, online shopping experienced time of prosperity. According to many experts, this trend will remain with us forever. People have learned to buy online, and this is much easier than a few years ago.

\section{Research of the literature}

There are many literature positions, both Polish and foreign language, which concern issues related to online stores. A comparative analysis of online stores requires a specialized knowledge that will introduce in details on trade in the network. In this chapter, points of view of individual authors of books or other fields of culture will be presented. The influence of a pandemic situation for internet trade will also be proven, which will help to reduce additional conclusions. In the book by Petr Weinlich and Tereza Semerádova "Website Quality and Shopping Behavior: Quantitative and Qualitative Evidence" [1], the author analyzes the impact of web design parameters on user experience and behavior. The author analyze the concept of website quality based on the identification of user behavior patterns in the online environment, with particular emphasis on the functional and aesthetic parameters of website design and the causal relationships between them. The website design is considered to be one of the key parameters of the company's presentation on the Internet, influencing consumer attitudes and purchasing behavior.

The website "similarweb.com" [2] compares the most popular websites around the world. The analysis took into account such factors as the average visit time on a given website, the average number of subpages that were visited during one visit, or the percentage of people who visited only one page when visiting a given online store. However, the most important factors that influenced the result are the total number of visits as well as the frequency of purchases. The data on this website is updated once a day, therefore the popularity of individual stores may change on this list on a daily basis. However, the first place is invariably occupied by Amazon, which has been winning the global ecommerce market for several years.

Yuan Gao in his book describes the design of Internet systems and consumer behavior on the Internet [3]. It takes an interdisciplinary approach to the design 
of systems in an online environment, providing an understanding of how consumers behave when shopping and how certain elements of system design can influence consumer perceptions, attitudes, intentions and actual behavior. He pays special attention to the time course of making purchases, which, in his opinion, should guide only the most important activities through the process, avoiding advertising elements at this point.

David Reibstein in the article "What attracts customers to online stores, and what keeps them coming back?" [4] tried to discover which tactic appeals to online shoppers the most and keeps them on the storefront. This study reveals surveys and behavioral data collected from online customers that reflect what was most important to online shoppers and compares pull and retention factors. As many believed that the Internet created better information for buyers, the question was how important the price would be in the buying process. It is clear from the analysis that what attracts customers to your site are not the same dimensions that are critical to customer retention in the long run.

Customer behavior covers a wide range of processes and activities related to sensory responses, perception, shaping attitudes, preferences, decisions, satisfaction assessment and loyalty building. Customer behavior on the Internet is influenced by exogenous and endogenous factors. External factors include attributes related to the e-merchant and the consumer's environmental influences. Endogenous factors include characteristics attributed to consumers. Of these, personality has a great influence on the behavior of customers in online stores. Costinel Dobre and Anca-Maria Milovan-Ciuta, in their article "Personality influences on online stores customers behavior" [5], draws attention to the influence of personality on important decision variables related to the customer's visit to the Internet, purchase and the post-purchase process, therefore he shows that the influence of personality on the criteria for assessing stores, the expectations of customers towards stores and the perception of the store's operation are important.

\section{Research methodology and determination the size of the research sample}

The purpose of the article is a comparison of online stores to learn about the differences in individual sites. Aspects such as the quality of the interface, service intuitiveness, security or popularity have been analysed using the survey method.

A survey was also carried out and awareness of individual sales platforms was checked, as well as the frequency of purchases on each of them. To select the appropriate number of people during the test, it was decided to use the sample selection calculator [6]. This is a minimum calculator, the required number of people on a sample from the population, assuming individual parameters. The given value informs how much people should investigate in the study to obtain a given minimum error value in the measurement at a fixed confidence level to a result of $95 \%$. To calculate the result, the size of the population is given in the form of eight million four hundred and sixty thousand. This is the equivalent of the Internet users in Poland with Internet users buying in foreign e-stores. In addition to the size of the population, two parameters remain for addition. This is the size of the fraction and maximum error. The size of the fraction, i.e. the percentage of the population, which exhibits a specific feature was set to 0.9 , i.e. it was assumed that the tested features occur in $90 \%$ of the population. Last parameter, i.e. the maximum error indicates what the highest value of the measuring error may occur in a given experience. A 5\% value has been set, which means that the result of the actual survey may differ. The result of the sample selection calculator showed a number 138 , which means that the minimum number of people in the study is required. The survey was made on an attempt of 169 people. This means that the calculator's assumptions have been met.

\section{Results of surveys of online stores users}

A study was conducted in which e-shops were examined. The survey was conducted among people who regularly shop online. It was created with the tool "Google Forms" [7], which was also used to process the survey. The survey was conducted on the "Facebook.com" [8] platform on groups related to online shopping. A survey consists of eight sections, each containing questions related to a specific issue. 169 respondents were examined. Table 1 shows as many as $79.3 \%$ are women. Men account for $20.7 \%$ of the respondents.

Table 1: Percentage of men and women participating in the study

\begin{tabular}{|c|c|}
\hline Gender & Percentage \\
\hline Men & $20.7 \%$ \\
\hline Women & $79.3 \%$ \\
\hline
\end{tabular}

Table 2 shows the percentage of respondents by age.

Table 2: Percentage of respondents by age

\begin{tabular}{|c|c|}
\hline Age & Percentage \\
\hline $18-24$ & $69.2 \%$ \\
\hline $25-34$ & $22.5 \%$ \\
\hline $35-44$ & $4.1 \%$ \\
\hline $45-54$ & $3.6 \%$ \\
\hline $55+$ & $0.6 \%$ \\
\hline
\end{tabular}

Table 3 shows the results about awareness of the users about online stores. Users were asked if they had ever heard of a given store. The "known" column shows the percentage of respondents who have heard about a given store as opposed to the "unknown" column.

Table 3: Awareness of the users about online stores

\begin{tabular}{|c|c|c|}
\hline Online store & Known & Unknown \\
\hline Allegro & $100 \%$ & $0 \%$ \\
\hline Amazon & $97 \%$ & $3 \%$ \\
\hline Aliexpress & $98.8 \%$ & $1.2 \%$ \\
\hline Ebay & $90.5 \%$ & $9.5 \%$ \\
\hline Wish & $77.5 \%$ & $22.5 \%$ \\
\hline
\end{tabular}


Table 4 shows the results about the frequency of making purchases on sales platforms.

Table 4: The frequency of making purchases on sales platforms

\begin{tabular}{|c|c|c|c|c|c|}
\hline $\begin{array}{c}\text { Online } \\
\text { store }\end{array}$ & Never & $\begin{array}{c}\text { Less } \\
\text { than } \\
\text { once a } \\
\text { month }\end{array}$ & $\begin{array}{c}1-3 \\
\text { times } \\
\text { per } \\
\text { month }\end{array}$ & $\begin{array}{c}4-6 \\
\text { times } \\
\text { per } \\
\text { month }\end{array}$ & $\begin{array}{c}\text { More } \\
\text { than 7 } \\
\text { times } \\
\text { per } \\
\text { month }\end{array}$ \\
\hline Allegro & $4.1 \%$ & $56.2 \%$ & $30.8 \%$ & $5.9 \%$ & $3 \%$ \\
\hline Amazon & $87.6 \%$ & $10.1 \%$ & $1.2 \%$ & $0.6 \%$ & $0.6 \%$ \\
\hline Aliexpress & $45 \%$ & $43.8 \%$ & $8.3 \%$ & $2.4 \%$ & $0.6 \%$ \\
\hline Ebay & $94.1 \%$ & $3.6 \%$ & $1.2 \%$ & $0.6 \%$ & $0.6 \%$ \\
\hline Wish & $95.3 \%$ & $3 \%$ & $1.2 \%$ & $0 \%$ & $0.6 \%$ \\
\hline
\end{tabular}

Table 5 shows the results about the interface. Users judged the overall appearance of the interface and they gave 1-5 mark on a five-point scale. Mark 1 if it's bad and 5 mark if it's good.

Table 5: Interface on a five-point scale

\begin{tabular}{|c|c|c|c|c|c|}
\hline $\begin{array}{c}\text { Online } \\
\text { store }\end{array}$ & 1 & 2 & 3 & 4 & 5 \\
\hline Allegro & $0 \%$ & $1.2 \%$ & $7.7 \%$ & $46.2 \%$ & $48.5 \%$ \\
\hline Amazon & $3.4 \%$ & $8.1 \%$ & $50.7 \%$ & $28.4 \%$ & $9.5 \%$ \\
\hline Aliexpress & $1.9 \%$ & $11 \%$ & $40 \%$ & $36.1 \%$ & $11 \%$ \\
\hline Ebay & $4.8 \%$ & $8.2 \%$ & $57.5 \%$ & $25.3 \%$ & $4.1 \%$ \\
\hline Wish & $6.3 \%$ & $18.3 \%$ & $57.7 \%$ & $15.5 \%$ & $2.1 \%$ \\
\hline
\end{tabular}

Table 6 shows the results about intuitiveness on a fivepoint scale. Users rated the ease of navigating the store and they gave 1-5 mark on a five-point scale. Mark 1 if it's bad and 5 mark if it's good.

Table 6: Intuitiveness on a five-point scale

\begin{tabular}{|c|c|c|c|c|c|}
\hline Online store & 1 & 2 & 3 & 4 & 5 \\
\hline Allegro & $0.6 \%$ & $1.8 \%$ & $4.1 \%$ & $27.8 \%$ & $65.7 \%$ \\
\hline Amazon & $4.9 \%$ & $9.2 \%$ & $47.2 \%$ & $26.1 \%$ & $12.7 \%$ \\
\hline Aliexpress & $5.2 \%$ & $11.8 \%$ & $32 \%$ & $28.8 \%$ & $22.2 \%$ \\
\hline Ebay & $4.4 \%$ & $10.2 \%$ & $52.6 \%$ & $24.1 \%$ & $8.8 \%$ \\
\hline Wish & $6.6 \%$ & $11.8 \%$ & $55.9 \%$ & $20.6 \%$ & $5.1 \%$ \\
\hline
\end{tabular}

Table 7 shows the number of times customers have bought products and never received them.

Table 7: Number of times the product was never received

\begin{tabular}{|c|c|c|c|c|}
\hline Online store & 0 & 1 & 2 & 3 or more \\
\hline Allegro & $91.7 \%$ & $6.5 \%$ & $0.6 \%$ & $1.2 \%$ \\
\hline Amazon & $97 \%$ & $2.2 \%$ & $0.7 \%$ & $0 \%$ \\
\hline Aliexpress & $59.3 \%$ & $15.3 \%$ & $11.3 \%$ & $14 \%$ \\
\hline Ebay & $97.7 \%$ & $2.3 \%$ & $0 \%$ & $0 \%$ \\
\hline Wish & $96 \%$ & $3.1 \%$ & $0 \%$ & $0.8 \%$ \\
\hline
\end{tabular}

Table 8 shows the percentage of respondents who most often choose the surveyed online store.

Table 8: Popularity of each online store

\begin{tabular}{|c|c|}
\hline Online store & Percentage \\
\hline Allegro & $85.7 \%$ \\
\hline Amazon & $1.2 \%$ \\
\hline Aliexpress & $12.5 \%$ \\
\hline Ebay & $0.6 \%$ \\
\hline Wish & $0.6 \%$ \\
\hline
\end{tabular}

\section{Analysis of research results}

Among the respondents, the Allegro online store is the most popular, as as many as $100 \%$ of respondents indicated that they have ever heard of it. It is certainly the most popular shopping platform in Poland. Asking a question about the knowledge of other platforms, i.e. Amazon, Aliexpress, Ebay and Wish, the majority of respondents replied that they had heard about them.

It can be clearly concluded that Allegro is the most frequently chosen store. Only $4.1 \%$ of the respondents say that they do not make purchases on this website, $39.7 \%$ declare that they make purchases more than once a month. The second place is taken by the Aliexpress store. More than every second respondent, as much as $55 \%$, make purchases on this sales platform. Despite the fact that shipping usually comes from abroad, Polish consumers are eager to buy there. The other platforms aren't so popular anymore. $87.6 \%$ of respondents declare that they do not shop on Amazon at all. Even more - $94.1 \%$ on Ebay, and Wish is the worst in the ranking, where $95.3 \%$ have never bought anything.

Allright, the interface is certainly very important in terms of website quality. After all, he is responsible for interacting with the user. The respondents were asked how they rate the interface of each eshop on a five-point scale from 1 to 5 . Additionally the survey results show that users rate its interface most often at 5 points on a five-point scale. Not a single person decided to give this website a grade of 1 . This shows that this store has a very good visual reception. For the remaining platforms, the number 3 was assigned the most frequently. This means that the respondents rated the interface of each of these stores on average. Aliexpress ranks second in the ranking, with $47.1 \%$ of respondents assessing the interface at 4 or 5 points. Wish online store is the worst in the ranking. Only three people decided to assign a score of five points. As many as $24.6 \%$ of people participating in the study assessed the borderline layout of the website below the average, because they assigned a score of one out of five points to $6.3 \%$ of the respondents and as many as $18.3 \%$ of the score two out of five. This is the worst result of all five sales platforms.

When examining intuitiveness, the author meant the ease of navigating through individual websites. The programmers have the greatest impact on intuitiveness, choosing the functionalities of websites so that the consumer can make a purchase as quickly and easily as possible. In the next compilation of the study, a fivepoint scale was used, as was the case with the interface quality. Thanks to this solution, it is easy to find out how the respondents assess which e-store is intuitive for them. Allegro is presented first, because it congratulates once again when comparing online stores. As many as $65.7 \%$ of respondents assessed the intuitiveness of this website as maximally and only one person gave the lowest score. The Aliexpress online store seems to be in second place again, because exactly $51 \%$ of respondents gave this service a 4 or 5 rating in terms of intuitiveness. The other websites show the same trend. Both Amazon, Ebay and Wish got more than $50 \%$ of the votes in the 
form of a three-point rating. This means that consumers rate the intuitiveness of these online stores on average.

Undoubtedly, one of the most important features of any online store is its security. When examining this factor, the author focused on the effectiveness of the delivery of the purchased product by a given e-shop to the consumer. The survey asked about an unfinished delivery, which resulted in the consumer not receiving the product. In particular, the interest in the results may be aroused by the Aliexpress website. $40.7 \%$ of the respondents replied that they had not received the purchased product at least once. As many as $14 \%$ of them claim that they have not received it more than 3 times. This result raises controversy whether the store is at all a safe place to shop online. All of them are more than ninety percent effective. Allegro achieved the lowest, $91.7 \%$ efficiency in delivery. The result may be due to the fact that consumers most often shop on this portal, therefore the statistical effectiveness is lower. However, despite the fact that Allegro is more popular than Aliexpress, Aliexpress is the least secure e-store for making purchases.

The vast majority, as much as $85.7 \%$ of Internet users, do their shopping on Allegro. The result of the study confirms other online sources, which also clearly show that this e-store is the most frequently chosen online store in Poland. Aliexpress is undoubtedly second. This portal is very popular because it offers very good prices. The other three websites are less popular. But it should be noted that still $2.4 \%$ of respondents choose them most often when shopping online.

\section{Conclusions}

A thorough analysis of selected online stores allowed us to define the strengths and weaknesses of individual websites, which are nowadays one of the most frequently chosen ways of making purchases by consumers. The surveyed group of respondents are people who mostly shop online. Allegro turns out to be the best of the five stores selected in the survey. The largest number of respondents assessed this website positively, both in terms of its interface and intuitiveness. Also, the vast majority feel safe when making purchases on this platform. The second most popular platform is, of course, the Aliexpress service. It encourages consumers with low prices, but this does not always translate into the final quality of purchases. Most of the respondents assessed its interface and intuitiveness on average. The website is definitely the worst in terms of transaction finalization, i.e. receiving the product. Many people declare that they have never received the purchased item despite placing an order. Certainly, the platform has potential, but it does not encourage customers there to continue shopping in the future. The other three platforms are not so popular with Polish consumers anymore. The respondents who use Amazon declare good security when making purchases there, but average intuitiveness. Ebay and Wish were also considered in this work. A small number of people shop there, despite being one of the largest sales platforms in the world. Users poorly declared their interface and average intuitiveness. It can be concluded that these parameters play a key role in the selection of online stores, as in the case of Allegro, Internet users assessed them at a fairly good level.

Consumers using online stores pay attention to many factors. They appreciate the legible graphic layout of the website and its simplicity. They pay attention to aspects such as safety and intuitiveness. Allegro can be considered a winner in comparison. This service is the most popular and encourages further purchases with transparency. However, it's good to be careful about the Aliexpress store. It is very likely that the goods ordered there may not be delivered.

\section{References}

[1] P. Weinlich, Website Quality and Shopping Behavior: Quantitative and Qualitative Evidence, Springer Nature, 2020.

[2] Website that researches online stores, https://www.similarweb.com/top-websites/category/ecommerce-and-shopping, [15.05.2021].

[3] Y. Gao, Web Systems Design and Online Consumer Behavior, Idea Group Publishing, 2004.

[4] D. J. Reibstein, What attracts customers to online stores, and what keeps them coming back?. J. of the Acad. Mark. Sci. 30, Journal of the Academy of Marketing Science, (2002) 465-473.

[5] C. Dobre, A. M. Milovan-Ciuta, Personality influences on online stores customers behavior, Ecoforum Journal, 4(1) (2015) 69.

[6] Sample selection calculator website, https://www.naukowiec.org/dobor.html, [11.05.2021].

[7] Website for creating online surveys, https://docs.google.com/forms, [17.05.2021].

[8] A social network where registered users can create networks and groups, https://www.facebook.com, [19.05.2021]. 